\title{
EMAP, an echinoderm microtubule-associated protein found in
} \section{microtubule-ribosome complexes}

\author{
Kathy A. Suprenant ${ }^{\star}$, Kathleen Dean, Julie McKee and Shelly Hake \\ 4010 Haworth Hall, Department of Physiology and Cell Biology, University of Kansas, Lawrence, Kansas 66045, USA and \\ the Marine Biological Laboratory, Woods Hole, MA 02543, USA
}

${ }^{*}$ Author for correspondence

\section{SUMMARY}

The major non-tubulin polypeptide found associated with microtubules purified from unfertilized sea urchin eggs by cycles of pH-dependent assembly has a $M_{\mathbf{r}}$ of 77,000. The 77,000 $M_{\mathrm{r}}$ polypeptide is heat- and acidlabile, and is antigenically distinct from the mammalian brain MAPs, MAP-2 and tau. Affinity-purified antiserum against the $77,000 M_{\mathrm{r}}$ polypeptide was used to survey a variety of cells and tissues for the presence of antigenically related polypeptides. A cross-reacting polypeptide, ranging in $M_{r}$ from 72,000 to 80,000 , was found in microtubule preparations from a wide variety of echinoderms, including sea urchins, starfish and sand dollars. Indirect immunofluorescence showed that the polypeptide was found in interphase as well as mitotic microtubule arrays. No cross-reacting material was detected in microtubules isolated from marine molluscs, mammalian brain or mouse B16 cultured cells. Because the 77,000 $M_{\mathrm{r}}$ MAP is abundant in echinoderms, we have called it EMAP for echinoderm microtubule-associated protein. Although the precise function of the EMAP is not known, our data suggest that the EMAP is involved in the attachment of ribosomes to microtubules. Large numbers of ribosomes are attached to the walls of EMAP-containing microtubules, but not EMAP-deficient microtubules. Removal of the EMAP from the microtubule by salt-extraction results in the release of ribosomes from the microtubule, indicating that the EMAP may form part or all of the long tapered stalk that connects these two organelles.

Key words: microtubule-associated proteins (MAPs), Lytechinus pictus, Strongylocentrotus purpuratus, Lytechinus variegatus, Arbacia punctulata, Echinarachnius parma, Asterias vulgaris, sea urchins, starfish, sand dollars, oocytes, ribosomes

\section{INTRODUCTION}

Microtubule-associated proteins (MAPs) are the major accessory proteins on microtubules, the prominent, cylindrical component of the cytoskeleton. Despite the essential roles performed by microtubules in eukaryotic cells, little is known regarding the function of the filamentous MAPs, other that those that serve as motor proteins. Structural and biochemical analysis has revealed a great deal about the in vitro behavior of neuronal MAPs (Olmsted, 1986; Wiche et al., 1991). In addition, recent transfection experiments have suggested that brain MAPs promote microtubule assembly and stabilize microtubule arrays in vivo (Lewis et al., 1989; Kanai et al., 1989), as well as alter the morphogenesis of neuronal cells (Dinsmore and Solomon, 1991; Baas et al., 1991). Yet, the deletion of the DNA sequence encoding a 205,000 $M_{\mathrm{r}}$ MAP from Drosophila results in viable animals with no detectable phenotype (Pereira et al., 1992). These results indicate that we are only beginning to sort out the functional complexity of these MAPs.

Mammalian brain has been a major source of microtubule protein for the past 20 years because it contains large quantities of tubulin and MAPs that readily assemble into micro- tubules in vitro. However, the bulk of this microtubule protein originates from cells that have stopped dividing. To identify MAPs and other regulatory factors that may regulate microtubule function during mitosis, we have developed methods for the purification of tubulin (Suprenant and Rebhun, 1983) and microtubule protein (Suprenant and Marsh, 1987; Suprenant et al. 1989) from unfertilized sea urchin egg extracts in the absence of taxol (Vallee and Bloom, 1983; Bloom et al., 1985; Vallee and Collins, 1986; Scholey et al. 1984, 1985; Hirokawa and Hisanaga, 1987; Hosoya et al., 1990). The unfertilized sea urchin egg contains a large store of tubulin (Raff et al., 1971) that becomes incorporated into the first cleavage mitotic apparatus (Bibring and Baxandall, 1977) and ciliated blastula (Bibring and Baxandall, 1981). Although there are no detectable microtubules in unfertilized sea urchin eggs (Harris et al., 1980), microtubules readily assemble in cytosolic extracts prepared at alkaline pH (Suprenant and Marsh, 1987). When purified by further cycles of assembly and disassembly, these microtubules are found to be composed principally of tubulin and a 77,000 $M_{\text {r }}$ polypeptide that coassembles stoichiometrically. Although this polypeptide has not been characterized, its abundance in these microtubule prepara- 
tions suggests that it may be involved in the formation and function of the first mitotic apparatus.

To determine if the 77,000 $M_{\mathrm{r}}$ coassembling polypeptide is a MAP, we have prepared and characterized a monospecific antiserum against the SDS-denatured polypeptide and have identified its intracellular location in both embryonic and somatic cells. Using this reagent, we have found that the $77,000 M_{\mathrm{r}}$ polypeptide is specifically associated with both interphase and mitotic microtubule arrays in vivo, but not with sperm flagellar microtubules. Moreover, this polypeptide may be involved in the interaction of the translational machinery with the cytoskeleton, as it appears to be involved in the binding of ribosomes to the microtubule walls. The abundance of this polypeptide in sand dollar, sea urchin and starfish eggs has led us to name this polypeptide EMAP for echinoderm microtubule-associated protein.

\section{MATERIALS AND METHODS}

\section{Sea urchin, sand dollar, surf clam, and starfish eggs, oocytes and sperm}

Surf clams (Spisula solidissima), starfish (Asterias vulgaris), sand dollars (Echinarachnius parma) and sea urchins (Arbacia punctulata) were provided by the Marine Resources Department at the Marine Biological Laboratory, Woods Hole, MA. The Pacific coast sea urchins, Strongylocentrotus purpuratus and Lytechinus pictus), were obtained from Marinus, Inc., Long Beach, CA. Susan Decker (Hollywood, FL) provided the Gulf Coast sea urchin (Lytechinus variegatus). Eggs and sperm from the sea urchins ( $S$. purpuratus, A. punctulata, L. pictus, and L. variegatus) and sand dollars (E. parma) were obtained by intracoelomic injection of $0.55 \mathrm{M} \mathrm{KCl}$. Sperm were collected "dry" and stored on ice until needed. Surf clam (S. solidissima) and starfish (A. vulgaris) oocytes were obtained by teasing apart ovaries into $\mathrm{Ca}^{2+}$-free artificial sea water $(436 \mathrm{mM} \mathrm{NaCl}, 9 \mathrm{mM} \mathrm{KCl}, 34 \mathrm{mM} \mathrm{MgCl} 2,16$ $\mathrm{mM} \mathrm{MgSO}_{4}, 1 \mathrm{mM}$ EGTA, $5 \mathrm{mM}$ Tris, $\mathrm{pH}$ 8.3). Eggs and oocytes were washed three times by settling through at least 20-30 volumes of $\mathrm{Ca}^{2+}$-free artificial sea water. S. purpuratus eggs were dejellied by washing once in isotonic "19:1" (500 mM NaCl, 27 $\mathrm{mM} \mathrm{KCl}, 2 \mathrm{mM}$ EDTA, pH 7.8). All other eggs were dejellied by two to three additional washes in $\mathrm{Ca}^{2+}$-free artificial sea water.

\section{Sea urchin coelomocytes}

Coelomocytes were isolated from the body cavity of the sea urchins $L$. variegatus, L. pictus and $S$. purpuratus exactly as described by Otto et al. (1979).

\section{Bovine brain tissue}

Microtubule protein was isolated from the brain cortex of freshly slaughtered beef cattle as described below for sea urchins.

\section{Squid optic lobe}

Squid (Loligo pealei) were obtained from the Department of Marine Resources, Marine Biological Laboratory, Woods Hole, MA. Microtubules were prepared from freshly dissected optic lobes as described below.

\section{Cultured mouse B16 melanoma cells}

B16 cells were grown in monolayer in Dulbecco's MEM with glucose, glutamine and $\mathrm{NaHCO}_{3}$, supplemented with $5 \%$ donor calf serum, at $37^{\circ} \mathrm{C}$ and in $5 \% \mathrm{CO}_{2}$. Cells were washed once with phosphate-buffered saline (PBS) and detached from culture vessels by trypsinization ( $0.01 \%$ trypsin, $0.1 \%$ EDTA in PBS). Cells were harvested by centrifugation $(5000 \mathrm{~g}, 5 \mathrm{~min})$ and washed twice in $1 \mathrm{mM}$ PMSF in PBS. Microtubules were prepared as described below from the pelleted cells $(6 \mathrm{~g}$ cells from $400 \mathrm{ml}$ culture).

\section{Microtubule protein}

For most experiments, microtubule protein was purified from eggs, oocytes, neuronal tissue and mouse B16 cells by the $\mathrm{pH}$ and temperature-dependent assembly methods of Suprenant and Marsh (1987) as modified by Suprenant et al. (1989). This microtubule protein is referred to as "cycle-purified microtubule protein". For some experiments, microtubule protein was purified from unfertilized eggs by the taxol method (Vallee and Bloom, 1983; Vallee and Collins, 1986). In addition, cold-labile microtubule protein was obtained from mitotic apparatuses isolated as previously described from first cleavage embryos (Keller and Rebhun, 1981; Suprenant, 1986).

\section{Measurement of protein concentration}

Protein concentrations were determined by the method of Lowry et al. (1951). Bovine serum albumin (BSA) was used as a protein standard.

\section{SDS-polyacrylamide gel electrophoresis and western blotting}

Proteins were analyzed on SDS-urea-polyacrylamide gels with the discontinuous buffer formulation of Laemmli (1970) as previously described (Suprenant et al., 1989). For quantitation of the 77,000 $M_{\mathrm{r}}$ MAP, gels were stained with Fast Green (Gorovsky et al. 1970) and quantitated by densitometry.

For western blot analysis, unstained SDS-polyacrylamide gels were electrophoretically transferred to nitrocellulose (BA-45, Schleicher and Schuell, Keene, NH) with a semi-dry blot cell (Janssen Life Sciences, Piscataway, NJ) according to the manufacturers' instructions. After air-drying, the blots were blocked for 1 hour at room temperature in blocking buffer: Tris-buffered saline (TBS: $10 \mathrm{mM}$ Tris- $\mathrm{HCl}, \mathrm{pH} 7.4,0.15 \mathrm{M} \mathrm{NaCl}$ ) containing 5\% (w/v) Carnation nonfat dry milk. After blocking, the blots were incubated overnight at $4^{\circ} \mathrm{C}$ with the affinity-purified rabbit antiserum against the $77,000 \mathrm{Mr}$ sea urchin microtubule-associated protein (see below). The blots were washed four times (10 minutes each) in TBS and subsequently incubated for 2 hours at room temperature with a 1:3000 dilution (into blocking buffer) of the alkaline phosphatase (AP)-conjugated goat anti-rabbit secondary antibody (Zymed Laboratories, San Francisco, CA). The blots were washed four times in TBS and were developed in for 5-15 minutes in $100 \mathrm{mM}$ Tris, $\mathrm{pH} 9.5,100 \mathrm{mM} \mathrm{NaCl}, 5 \mathrm{mM} \mathrm{MgCl} 2$ containing $132 \mu \mathrm{l}$ nitroblue tetrazolium $(50 \mathrm{mg} / \mathrm{ml}$ in $70 \%$ dimethyl formamide) and $66 \mu 1$ 5-bromo-4-chloro-3-indoly-phosphate $(50 \mathrm{mg} / \mathrm{ml}$ in $100 \%$ dimethyl formamide) (Blake et al., 1984).

\section{Generation of polyclonal antiserum}

Rabbit (New Zealand) pre-immune serum was collected and examined by immunofluorescence for the presence of autoantibodies that reacted with sea urchin ( $S$. purpuratus embryos at first mitotic cleavage) or mammalian cytoskeletal proteins (mouse B16 cultured melanoma cells). Rabbits with preimmune serum against cytoskeletal proteins were not used. An immune serum was prepared against the 77,000 $M_{\mathrm{r}}$ polypeptide that coassembled with $S$. purpuratus egg microtubules. Microtubule protein was separated on a $3 \mathrm{~mm}$ thick preparative SDS-polyacrylamide gel (4\% to $16 \%$ acrylamide and $1 \mathrm{M}$ to $8 \mathrm{M}$ urea gradient). The gel was stained briefly with $0.5 \%$ Coomassie blue R-250 in $40 \%$ methanol and $10 \%$ acetic acid and then destained in $25 \%$ methanol and $10 \%$ acetic acid. The band corresponding to the $77,000 M_{\mathrm{r}}$ polypeptide was cut out and chopped into $2 \mathrm{~mm}$ square segments. The gel slices were washed 
four times in distilled water (30 minutes each wash) and once in electro-dialysis buffer that contained $2.5 \mathrm{mM}$ Tris, $19 \mathrm{mM}$ glycine, and $0.1 \%(\mathrm{w} / \mathrm{v})$ SDS. The protein was electroeluted from the gel slices at $200 \mathrm{~V}$ for 6 hours. The eluted protein was dialyzed against phosphate-buffered saline (PBS: $20 \mathrm{mM}$ sodium phosphate, 0.13 $\mathrm{M} \mathrm{NaCl}, \mathrm{pH}$ 7.4). The dialyzed protein was emulsified with an equal volume of Freund's complete adjuvant and injected intradermally. The rabbit was boosted subcutaneously on days 21,28 , 42 and 49 with dialyzed protein emulsified with incomplete adjuvant. Ten to fifteen $\mathrm{ml}$ of serum were collected 7 days after each boost, and once a month for the following year. Clotted serum was cleared by centrifugation (1000 $\boldsymbol{g}_{\max }, 20$ minutes, Beckman JA-20 rotor) and stored frozen at $-20^{\circ} \mathrm{C}$.

\section{Blot-affinity purification of antiserum}

The 77,000 $M_{\mathrm{r}}$ antiserum was mixed for 20 minutes on ice with an equal volume of ice-cold, saturated ammonium sulfate containing $10 \mathrm{mM} \mathrm{K}^{+}$-EDTA, pH 7.0. The IgG-containing fraction precipitated and was collected by centrifugation at 14,000 revs/min for 20 minutes (JA-20 rotor). The pellet was washed three times by resuspension in saturated ammonium sulfate (above), followed by centrifugation. The pellet was resuspended in ice-cold PBS and dialyzed against several changes of PBS. The IgG fraction was affinity purified from nitrocellulose blots as described by Smith and Fisher (1984), concentrated with a Centricon 30 microconcentrater (Amincon Corp., Danvers, MA) and stored at $4^{\circ} \mathrm{C}$.

\section{Immunofluorescence light microscopy}

S. purpuratus embryos were attached to poly(L-lysine)-coated glass coverslips, extracted in $25 \mathrm{mM} \mathrm{MES} / \mathrm{K}^{+}, \mathrm{pH} 6.7,10 \mathrm{mM}$ EGTA, $0.5 \mathrm{mM} \mathrm{MgCl} 2,25 \%$ glycerol, $25 \mathrm{mM}$ PMSF and $1 \%$ Nonidet P-40 (Balzcon and Schatten, 1981) and fixed at $-20^{\circ} \mathrm{C}$ in 90\% methanol containing $50 \mathrm{mM}$ EGTA (Harris et al., 1980). Embryos were rehydrated in PBS and incubated for 30 minutes at $37^{\circ} \mathrm{C}$ with the affinity-purified anti-77,000 $M_{\mathrm{r}}$ antiserum. After five gentle washes with PBS, the coverslip-attached embryos were incubated for 30 minutes, at $37^{\circ} \mathrm{C}$ with a Texas Red-conjugated secondary antibody. Embryos were washed as before and mounted in $90 \%$ glycerol in $0.1 \mathrm{M} \mathrm{Na}_{2} \mathrm{HPO}_{4}, \mathrm{pH} 9.0$.

Coelomocytes were permeabilized in methanol at $-20^{\circ} \mathrm{C}$, fixed in $1.5 \%$ formalin, and processed for immunofluorescence as described (Otto et al., 1979).

Sea urchin sperm were diluted into $\mathrm{Ca}^{2+}$-free artificial sea water and adsorbed onto poly(L-lysine)-coated coverglass. Sperm were fixed at $-20^{\circ} \mathrm{C}$ with methanol-EGTA and processed for immunofluorescence.

\section{Electron microscopy}

Microtubule pellets were fixed and embedded for thin-sectioning as previously described (Suprenant and Marsh, 1987).

\section{RESULTS}

\section{A 77,000 $M_{\mathrm{r}}$ polypeptide coassembles with sea urchin microtubules assembled at alkaline $\mathrm{pH}$}

In this study, microtubules were purified from unfertilized sea urchin egg extracts by cycles of $\mathrm{pH}$ - and temperaturedependent assembly (Suprenant and Marsh, 1987; Suprenant et al., 1989). The major non-tubulin component of these microtubules is a 77,000 $M_{\text {r }}$ polypeptide (Fig. 1A). Several other higher and lower molecular weight polypeptides are present at reduced levels. Filamentous projections, similar to those produced by the mammalian brain MAPs, are not found on sea urchin microtubules assembled in vitro

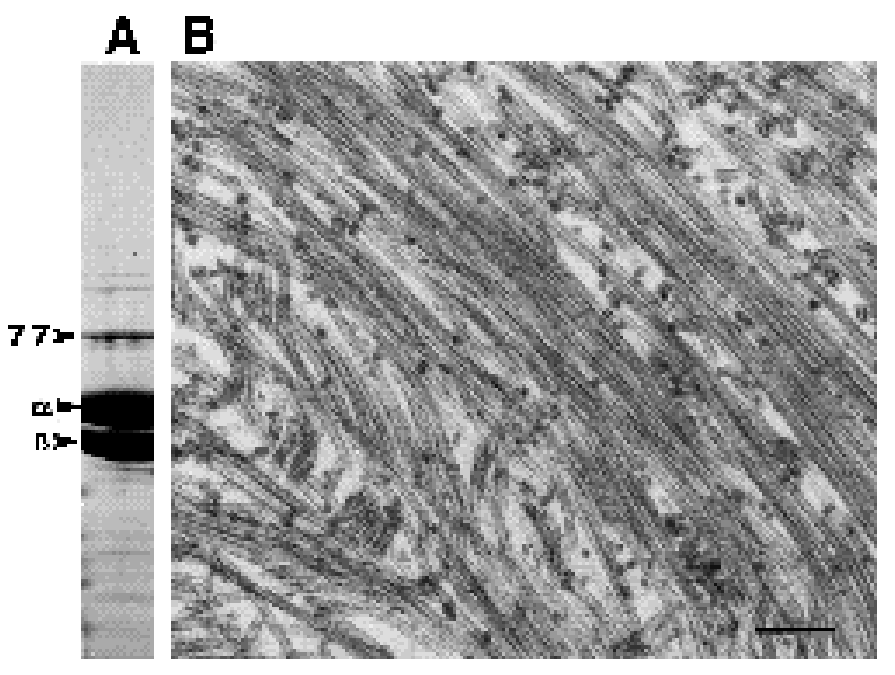

Fig. 1. Purification of microtubules from unfertilized sea urchin (Strongylocentrotus purpuratus) eggs. (A) SDS-PAGE gel shows that a 77,000 $M_{\mathrm{r}}$ polypeptide and $\alpha$ and $\beta$ tubulin are the major microtubule proteins. (B) Electron micrograph of egg microtubules with associated ribosomes. Bar, $200 \mathrm{~nm}$.

(Fig. 1B). In contrast, microtubules are decorated with large globular structures, previously identified as ribosomes (Suprenant et al., 1989). In this previous study, we demonstrated that the ribosomes are attached to microtubules by ionic interactions through a long tapered stalk. A potential candidate for this stalk is the 77,000 $M_{\mathrm{r}}$ polypeptide (and presumptive MAP). In addition to interacting with the translational machinery, the $77,000 M_{\mathrm{r}}$ polypeptide may regulate microtubule dynamics during the embryonic cell cycles. To begin to understand the function of this protein, we have examined its abundance, its conservation among echinoderms and its intracellular location in embryonic and differentiated cells.

The 77,000 $M_{\mathrm{r}}$ polypeptide is a major component of microtubule preparations from a wide variety of sea urchins including cold water (S. purpuratus, L. pictus) and warm water species (L. variegatus, A. punctulata). Among the four different species of urchins examined, the "77,000 $M_{\mathrm{r}}$ " polypeptide varied both in its relative abundance and its migration on SDS-PAGE. Consistently, the largest amounts of this polypeptide were found in microtubules isolated from the warm water urchins. The stoichiometric extremes are illustrated in Fig. 2. For quantitation, purified microtubule protein from $S$. purpuratus and A. punctulata were compared side-by-side on Fast green-stained acrylamide gels. Densitometric analysis of these gels indicates that a $75,000 M_{\mathrm{r}}$ and a 77,000 $M_{\mathrm{r}}$ polypeptide comprises $17 \%$ by mass of the A. punctulata microtubules and $6 \%$ by mass of the $S$. purpuratus microtubules, respectively. The molar ratio of the $75,000 M_{\mathrm{r}}$ and $77,000 M_{\mathrm{r}}$ polypeptides to tubulin dimer is $0.22 \pm 0.01$ and $0.08 \pm 0.02$ for $A$. punctulata and $S$. purpuratus microtubules, respectively.

\section{Generation of a monospecific antiserum against the 77,000 $M_{r}$ polypeptide}

Attempts to purify sufficient quantities of EMAP for bio- 

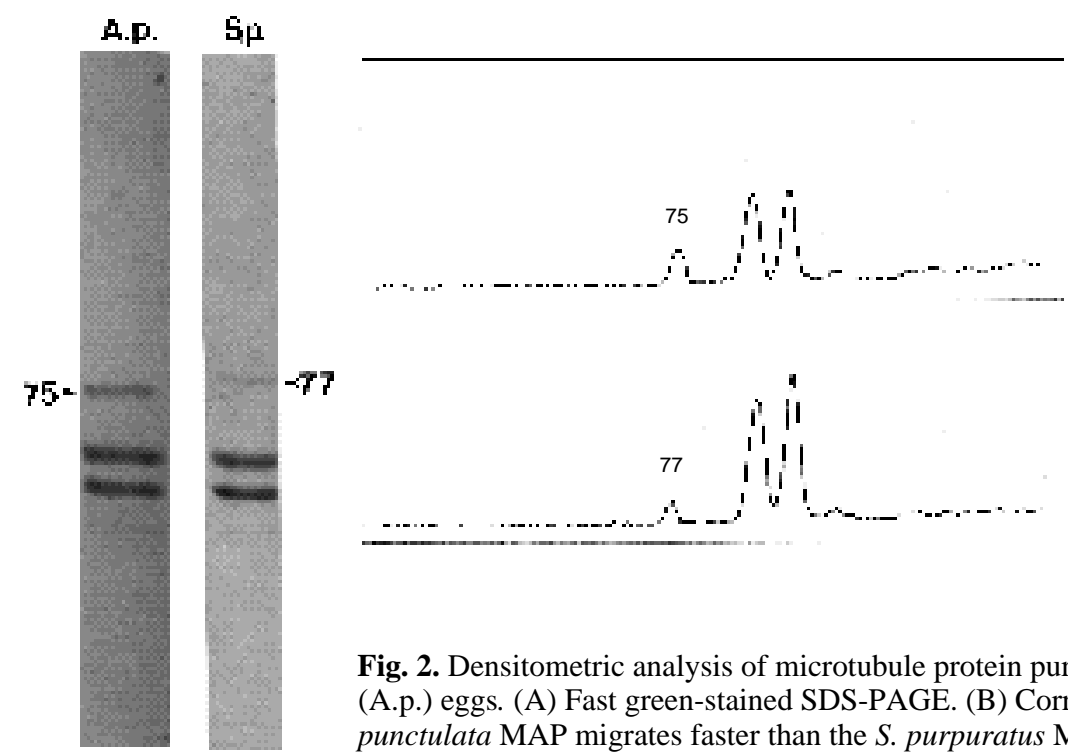

chemical analysis have been largely unsuccessful. EMAP binds weakly to cation-exchange columns such as carboxymethylcellulose, traditionally used to purify MAPs (Weingarten et al., 1975; Williams and Detrich, 1979). Because of difficulties in the purification of this polypeptide, an immunological approach was utilized for the initial characterization. The 77,000 $M_{\mathrm{r}}$ polypeptide from $S$. pur puratus cycle-purified microtubule preparations was used as an immunogen in rabbits. The polyclonal antiserum generated against the SDS-denatured 77,000 $M_{\mathrm{r}}$ band recognizes the 77,000 $M_{\mathrm{r}}$ polypeptide on western blots (Fig. 3AC). This antiserum is highly reactive and shows significant binding to the $77,000 M_{\mathrm{r}}$ polypeptide at dilutions of $1: 10,000$ and greater. In addition, the antibody recognizes native protein that has been blotted directly to nitrocellulose (data not shown). A monospecific IgG fraction was purified from the crude antiserum by ammonium sulfate precipitation and affinity-purification from nitrocellulose blots containing the 77,000 $M_{\mathrm{r}}$ polypeptide (Smith and Fisher, 1984). The affinity-purified anti-77,000 $M_{\mathrm{r}} \mathrm{IgG}$ recognizes a single polypeptide band of $M_{\mathrm{r}} 77,000$ in whole egg homogenates (Fig. 3D,E); however, the 77,000 $M_{\mathrm{r}}$ polypeptide is not detectable in flagellar axonemes (Fig. $3 \mathrm{~F}, \mathrm{G})$.

\section{Microtubules in embryonic and somatic cells are stained with the $77,000 M_{\mathrm{r}}$ antiserum}

First cleavage embryos were probed with the affinity-purified anti-77,000 $M_{\mathrm{r}}$ antibodies (Fig. 4). The mitotic apparatus is prominently labeled with this antibody and the staining pattern is frequently along linear tracks presumed to be microtubules. Immunostaining was distributed throughout the spindle, although astral regions of the spindle appear to be stained more intensely than the central spindle regions. The antibody stains the mitotic spindle apparatus of all the sea urchins examined in this study.

To compare the localization of the 77,000 $M_{\mathrm{r}}$ polypeptide in mitotic cells with that in interphase cells, we examined sea urchin coelomocytes. The coelom or body cavity of the adult sea urchin contains several different types of coelomocytes (Edds, 1985; Smith, 1981). One coelomocyte, the phagocytic amoebocyte, can be purified in large numbers from the coelomic fluid and will adhere and spread on a glass coverslip into their characteristic petaloid shape (Fig. 5A). These adult somatic cells are terminally differ-

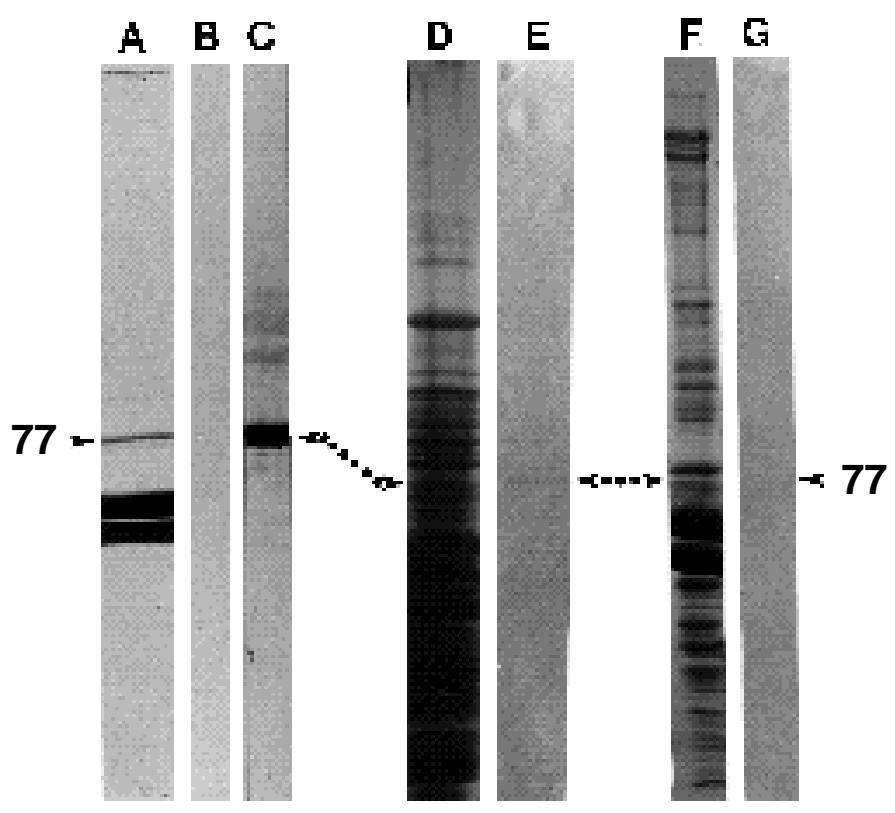

Fig. 3. Immunoblot analysis of the polyclonal antibody generated against the 77,000 $M_{\mathrm{r}}$ polypeptide. (A) Electrophoretic analysis of S. purpuratus egg microtubule protein stained with Coomassie blue. Corresponding immunoblot with preimmune serum (B) and unfractionated anti-77,000 $M_{\mathrm{r}}$ antiserum (C). (D) Proteins in a whole-egg homogenate separated by SDS-PAGE and corresponding immunoblot with the affinity-purified anti-77,000 $M_{\mathrm{r}}$ IgG. (F) Electrophoretic separation of axonemal proteins from sea urchin sperm and corresponding immunoblot with the affinitypurified anti-77,000 $M_{\mathrm{r}} \operatorname{IgG}(\mathrm{G})$. The 77,000 $M_{\mathrm{r}}$ polypeptide is detectable in eggs but not sperm. Arrowheads and dotted lines indicate the location of the 77,000 $M_{\mathrm{r}}$ polypeptide on gels of different proportion. 

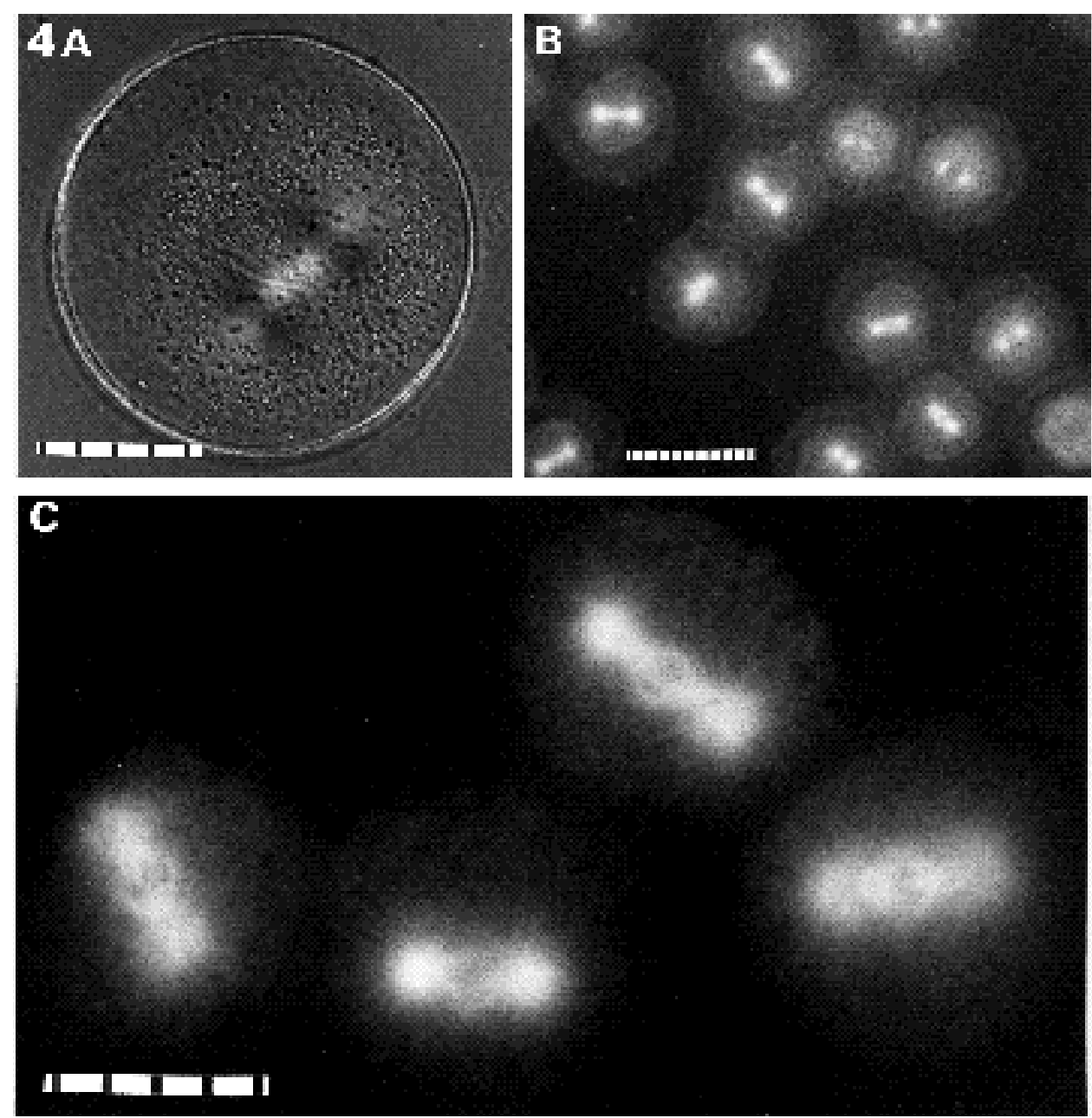

Fig. 4. Immunofluorescence staining of first cleavage sea urchin embryos. (A) Extracted embryo viewed in polarized light prior to immunofluorescence. (B, C) Staining of $S$. purpuratus mitotic apparatus with the affinity-purified anti-77,000 $M_{\mathrm{r}}$ IgG. The $77,000 M_{\text {r }}$ polypeptide is detectable in spindles at all stages of mitosis. Bar, $10 \mu \mathrm{m}$ spacing. entiated and do not divide. Because these cells contain fewer microtubules than the first cleavage embryos and their interphase microtubule array is flattened and nearly two-dimensional, these cells are ideal for immunolocalization studies. In addition, coelomocytes can be prepared for immunofluorescence without detergent extraction, a procedure that can sometimes cause the redistribution of soluble antigens (Melan and Sluder, 1992).

Fig. 5B-E illustrates the petaloid coelomocyte staining pattern with DM1A, a monoclonal antibody against $\alpha$ tubulin, and with the affinity-purified anti-77,000 $M_{\mathrm{r}}$ IgG. Individual microtubules can be visualized by immunofluorescence staining with the DM1A anti-tubulin antibody. The coelomocyte microtubules appear to originate near the nucleus and extend outwards toward the cell periphery. The affinity-purified anti-77,000 $M_{\mathrm{r}}$ IgG also stains the coelomocytes in a pattern similar to that of the DM1A tubulin staining. Curvilinear tracks, presumed to be microtubules extend radially outward from the nucleus. The staining pattern becomes diffuse and barely detectable when the cells are treated with nocodazole (data not shown). These results indicate that the $77,000 M_{\mathrm{r}}$ polypeptide is microtubule-associated. It is interesting that both the anti-tubulin and anti$77,000 M_{\mathrm{r}}$ staining patterns are perinuclear, not pericentriolar. There is no obvious focal nucleation center in these cells at any plane of focus.
The 77,000 $M_{\mathrm{r}}$ MAP is detectable only on cytoplasmic or mitotic microtubule arrays. Immunofluorescence microscopy failed to reveal any cross-reacting structure in intact sperm (Fig. 6). Although the sperm tail stains brightly with the anti-tubulin antibody, there was no detectable staining of the flagellum with the anti-77,000 $M_{\mathrm{r}}$ IgG. This confirms the western blot results shown in Fig. 3 .

\section{The $77,000 M r$ MAP is present in mitotic apparatus microtubules and in taxol-polymerized microtubules}

Several MAPs of similar $M_{\mathrm{r}}$ have been identified in microtubule preparations from sea urchin eggs. Keller and Rebhun (1982) identified an 80,000 Mr MAP from $S$. pur puratus mitotic apparatuses that copurified with spindle tubulin. Bloom and coworkers used a taxol-dependent procedure to purify microtubules from unfertilized L. variega tus and $S$. purpuratus eggs and identified four MAPs of $M_{\mathrm{r}}$ 205,000, 120,000, 100,000 and 77,000 (Vallee and Bloom, 1983; Bloom et al. 1985). In a similar report, an 80,000 $M_{\mathrm{r}}$ MAP was identified in taxol-microtubule preparations from S. purpuratus, L. pictus and S. droebachiensis (Scholey et al., 1984). Finally, Hirokawa and Hisanaga (1987) used gel filtration chromatography to purify a 75,000 $M_{\mathrm{r}}$ MAP from taxol-microtubules isolated from unfertilized eggs of the sea 

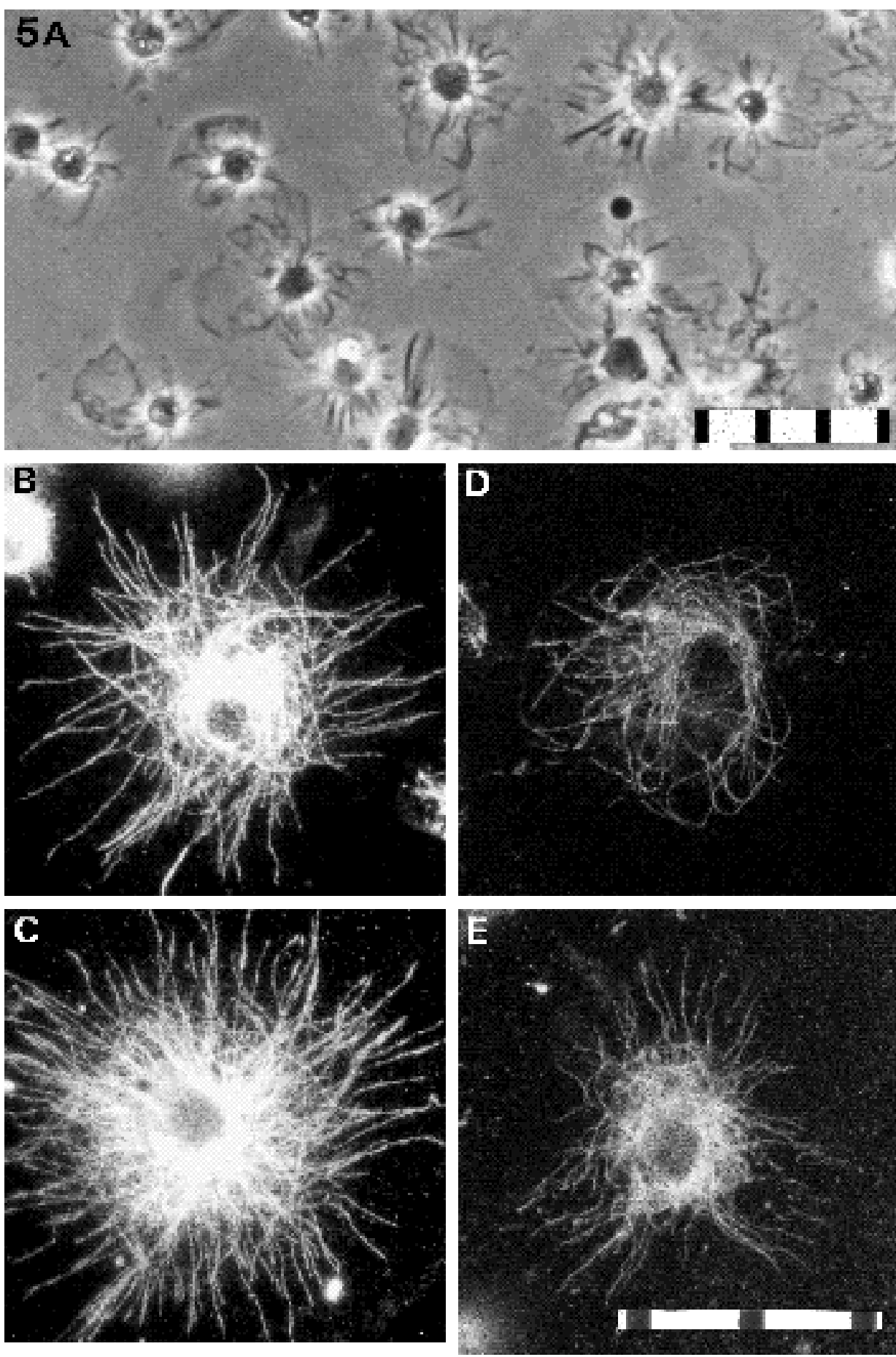

Fig. 5. Immunofluorescence microscopy of $L$. variegatus coelomocytes. (A) Phase-contrast micrograph of petaloid coelomocytes purified from the sea urchin L. variegatus. Coelomocyte staining pattern with DM1A anti-tubulin antibody $(\mathrm{B}, \mathrm{C})$ or the affinity-purified anti-77,000 $M_{\mathrm{r}} \mathrm{IgG}$ $(\mathrm{D}, \mathrm{E})$. A different coelomocyte is shown in each panel. Similar staining patterns were observed in coelomocytes isolated from $L$. pictus and $S$. purpuratus. Bar, 10 $\mu \mathrm{m}$ spacing. urchins Pseudocentrotus depressus and Hemicentrotus pul cherrimus.

To determine whether the 75,000 to $80,000 M_{\mathrm{r}}$ taxol MAPs (Vallee and Bloom, 1983; Bloom et al., 1985; Scholey et al., 1984; Hirokawa and Hisanaga, 1987) and the $80,000 M_{\mathrm{r}}$ spindle MAP (Keller and Rebhun, 1980; Rebhun et al., 1982) are antigenically related to the $77,000 M_{\mathrm{r}}$ cyclepurified MAP, these microtubule proteins were isolated and blotted with the anti-77,000 $M_{\mathrm{r}}$ antiserum. On a urea and acrylamide gradient gel, a complex pattern of polypeptides is observed in the $77,000 M_{\mathrm{r}}$ region of the taxol-microtubule preparation (Fig. 7a,b). Three bands with $M_{\mathrm{r}}$ values of 78,000, 80,000 and 82,000, are observed in L. pictus microtubule preparations. The affinity-purified anti-77,000 $M_{\mathrm{r}}$ IgG recognizes a single band that corresponds to the most abundant polypeptide migrating with an apparent $M_{\mathrm{r}}$ of 80,000 (Fig. 7a', $\mathrm{b}^{\prime}$ ). The L. pictus MAP migrates with a slightly larger $M_{\mathrm{r}}$ than the $S$. purpuratus MAP regardless of whether it was taxol- or cycle-purified.

In a separate experiment, L. pictus eggs were fertilized and allowed to develop to the first mitotic metaphase. Mitotic apparatuses were isolated as previously described 

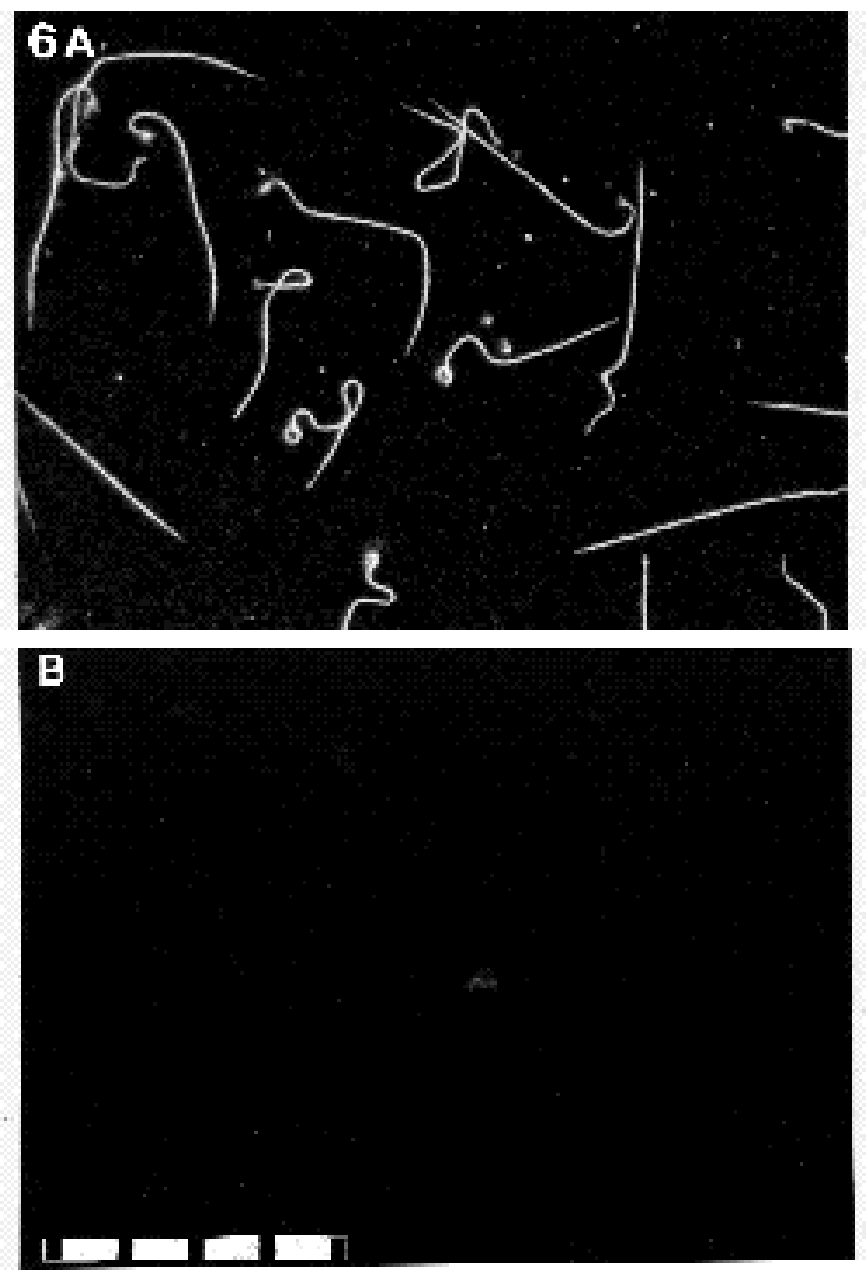

Fig. 6. Immunofluorescence microscopy of $S$. purpuratus sperm with the DM1A anti-tubulin antibody (A) and the affinity-purified anti-77,000 $M_{\mathrm{r}} \operatorname{IgG}(\mathrm{B})$. The 77,000 $M_{\mathrm{r}}$ polypeptide is not detectable in sea urchin sperm shown in B. Bar, $10 \mu \mathrm{m}$ spacing.

(Keller and Rebhun, 1981; Suprenant, 1986) and placed on ice to depolymerize the mitotic microtubules. After centrifugation, a cold-labile microtubule fraction was separated from the insoluble spindle remnant. Proteins from these two fractions were separated by electrophoresis and immunoblotted with the affinity-purified anti-77,000 $M_{\mathrm{r}}$ IgG (Fig. 7c,d,e). As can be seen on the Coomassie bluestained gel, most of the tubulin and all of the detectable $80,000 M_{\mathrm{r}}$ MAP is solubilized in the cold. Only traces of $80,000 M_{\mathrm{r}}$ MAP are found in the spindle remnant. Again, the anti-77,000 $M_{\mathrm{r}} \mathrm{IgG}$ recognizes a single polypeptide in the soluble microtubule fraction that corresponds to the previously identified 80,000 $M_{\mathrm{r}}$ spindle MAP (Fig. $7 \mathrm{c}^{\prime}, \mathrm{d}^{\prime}, \mathrm{e}^{\prime}$ ).

\section{The 77,000 $M_{\mathrm{r}}$ polypeptide is abundant in echinoderm microtubule preparations}

The 77,000 $M_{\mathrm{r}}$ MAP is not restricted to sea urchin eggs and coelomocytes. Microtubules were purified from a variety of marine eggs and tissues by cycles of $\mathrm{pH}$ - and temperature-dependent assembly, and immunoblotted with the affinity-purified anti-77,000 $M_{\mathrm{r}}$ antibody (Fig. 8). Micro-
Table 1. Presence or absence of the 77,000 $M_{\mathbf{r}}$ MAP in several species

\begin{tabular}{|c|c|c|}
\hline & Presence & Absence \\
\hline \multicolumn{3}{|l|}{ Phylum Echinodermata } \\
\hline \multicolumn{3}{|l|}{ Sea urchin eggs and coelomocytes } \\
\hline Strongylocentrotus purpuratus & + & \\
\hline Lytechinus pictus & + & \\
\hline Lytechinus variegatus & + & \\
\hline Arbacia punctulata & + & \\
\hline \multicolumn{3}{|l|}{ Sea urchin sperm flagella } \\
\hline Strongylocentrotus purpuratus & & + \\
\hline Lytechinus pictus & & + \\
\hline \multicolumn{3}{|l|}{ Starfish oocytes } \\
\hline Asterias vulgaris & + & \\
\hline \multicolumn{3}{|l|}{ Sand dollar eggs } \\
\hline Echinarachnius parma & + & \\
\hline \multicolumn{3}{|l|}{ Phylum Mollusca } \\
\hline \multicolumn{3}{|l|}{ Clam oocytes } \\
\hline Spisula solidissima & & + \\
\hline \multicolumn{3}{|l|}{ Squid optic lobe } \\
\hline Loligo pealei & & + \\
\hline \multicolumn{3}{|l|}{ Subphylum Vertebrata } \\
\hline \multicolumn{3}{|l|}{ Brain microtubule protein } \\
\hline Bos tauris & & + \\
\hline \multicolumn{3}{|l|}{ B16 cultured melanoma cells } \\
\hline Mus musculus & & + \\
\hline \multicolumn{3}{|c|}{$\begin{array}{l}\text { Several species of animals were examined by western blotting and } \\
\text { immunofluorescence techniques for the presence of the } 77,000 M_{\mathrm{r}} \text { MAP. } \\
\text { The abundance of this polypeptide in sand dollar, sea urchin and starfish } \\
\text { has led us to name this polypeptide EMAP for echinoderm microtubule- } \\
\text { associated protein. }\end{array}$} \\
\hline
\end{tabular}

tubule preparations from starfish oocytes contain large quantities of a 72,000 $M_{\mathrm{r}}$ polypeptide that is antigenically related to the $77,000 M_{\mathrm{r}}$ sea urchin MAP (Fig. 8b,b'). Microtubules were also purified from E. parma, an Atlantic coast sand dollar. On Coomassie blue-stained gels there are few detectable MAPs in the sand dollar preparation; however, an immunoblot of the same microtubule protein identifies two proteins of $M_{\mathrm{r}} 80,000$ and 100,000 that react strongly with the anti-77,000 $M_{\mathrm{r}}$ antibody (Fig. 8f, $\mathrm{f}^{\prime}$ ). In contrast, no cross-reacting material was detected in microtubule preparations from marine molluscs, including surf clam oocytes ( $S$. solidissima) and squid optic lobe ( $L$. pealei); although other putative MAPs are present in these preparations. Similarly, no antigenically related polypeptides were detected in bovine brain microtubule preparations or in mouse B16 cultured melanoma cells. These results are summarized in Table 1.

\section{EMAP is distinct from MAP-2 and tau}

EMAP and the vertebrate brain MAPs appear to be antigenically distinct. The antiserum against the EMAP fails to react with any MAP in bovine brain microtubule preparations (Fig. 8e,e'). In addition, monoclonal antibodies against MAP-2 or tau (tau-1 and AP-14, kindly provided by L. Binder, University of Alabama, Birmingham) fail to recognize the 77,000 $M_{\mathrm{r}}$ sea urchin MAP (data not shown). Unlike vertebrate MAPs, EMAP is not heat-stabile. S. pur puratus microtubule protein was resuspended in ice-cold buffer containing $100 \mathrm{mM}$ PIPES/K $\mathrm{K}^{+}(\mathrm{pH}$ 6.9), $1 \mathrm{mM}$ EGTA, $1 \mathrm{mM} \mathrm{MgSO}_{4}, 2 \mathrm{mM}$ DTT, $1 \mathrm{mM} \mathrm{GTP,} 0.2 \mathrm{mM}$ PMSF, $3 \mu \mathrm{g} / \mathrm{ml}$ leupeptin and $10 \mu \mathrm{g} / \mathrm{ml}$ pepstatin. After a 


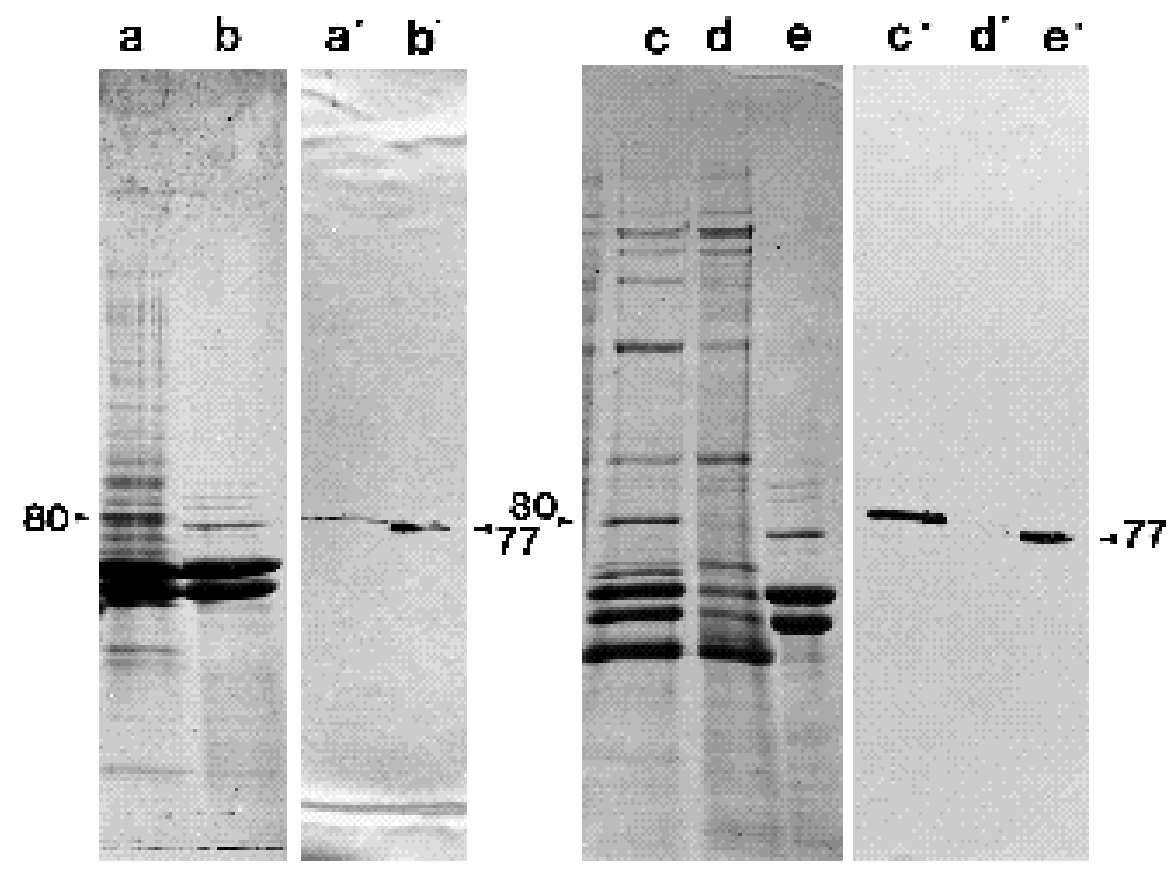

Fig. 7. Evidence that the taxol MAP and $80,000 M_{\mathrm{r}}$ spindle MAP from $L$. pictus are antigenically related to the $77,000 M_{\mathrm{r}}$ cycle-purified MAP. SDS-PAGE of taxol microtubules from L. pictus (a) and cyclepurified microtubules from $S$. purpuratus (b) and their corresponding immunoblot with the affinity-purified anti-77,000 $M_{\mathrm{r}}$ IgG $\left(\mathrm{a}^{\prime}, \mathrm{b}^{\prime}\right)$. The corresponding MAP in $L$. pictus migrates with an apparent $M_{\mathrm{r}}$ of 80,000 . To identify the $80,000 M_{\mathrm{r}}$ spindle MAP, mitotic apparatuses were isolated from L. pictus embryos and placed on ice to depolymerize microtubules. After a brief centrifugation the cold-labile microtubule protein (c) was separated from the insoluble spindle remnants (d).

The protein composition of $S$. purpuratus cycle-purified microtubule protein is compared with this protein on this Coomassie blue-stained SDS-PAGE gel (e). The corresponding immunoblot with the affinity-purified anti-77,000 $M_{\mathrm{r}} \mathrm{IgG}$ is shown on the right $\left(\mathrm{c}^{\prime}, \mathrm{d}^{\prime}, \mathrm{e}^{\prime}\right)$. The position of the 77,000 $M_{\mathrm{r}}$ cycle-purified MAP from $S$. purpuratus is shown. The corresponding MAP in L. pictus mitotic apparatuses also migrates with a higher apparent $M_{\mathrm{r}}$ of 80,000.

30-minute incubation on ice to depolymerize the microtubules completely, the solution was immersed into a $100^{\circ} \mathrm{C}$ water bath for 5 minutes. After centrifugation $(39,000 \mathrm{~g}$, 30 minutes, $4^{\circ} \mathrm{C}$ ), the soluble supernatant fraction and resuspended pellets were analyzed by SDS-PAGE. All the detectable 77,000 $M_{\mathrm{r}}$ polypeptide is in the heat-denatured pellet fraction. Finally, unlike mammalian tau protein (Lindwall and Cole, 1984), the 77,000 $M_{\mathrm{r}}$ sea urchin MAP is completely insoluble in $2.5 \%$ perchloric acid (data not shown). These results indicate that EMAP may belong to a unique class of microtubule-associated proteins distinct from the vertebrate brain MAPs.

\section{EMAP may be involved in ribosome attachment to microtubules}

There is a strong correlation between the presence of the $77,000 M_{\mathrm{r}}$ EMAP and the interaction of ribosomes with microtubules assembled in vitro. Electron microscopy reveals that ribosomes are absent in microtubule preparations where the EMAP is not detectable (Fig. 9). In contrast, ribosomes are abundant in EMAP-containing microtubules. These results suggest that ribosomes do not randomly bind to microtubules assembled under our buffer conditions, but rather they associate with a specific MAPcontaining microtubule.
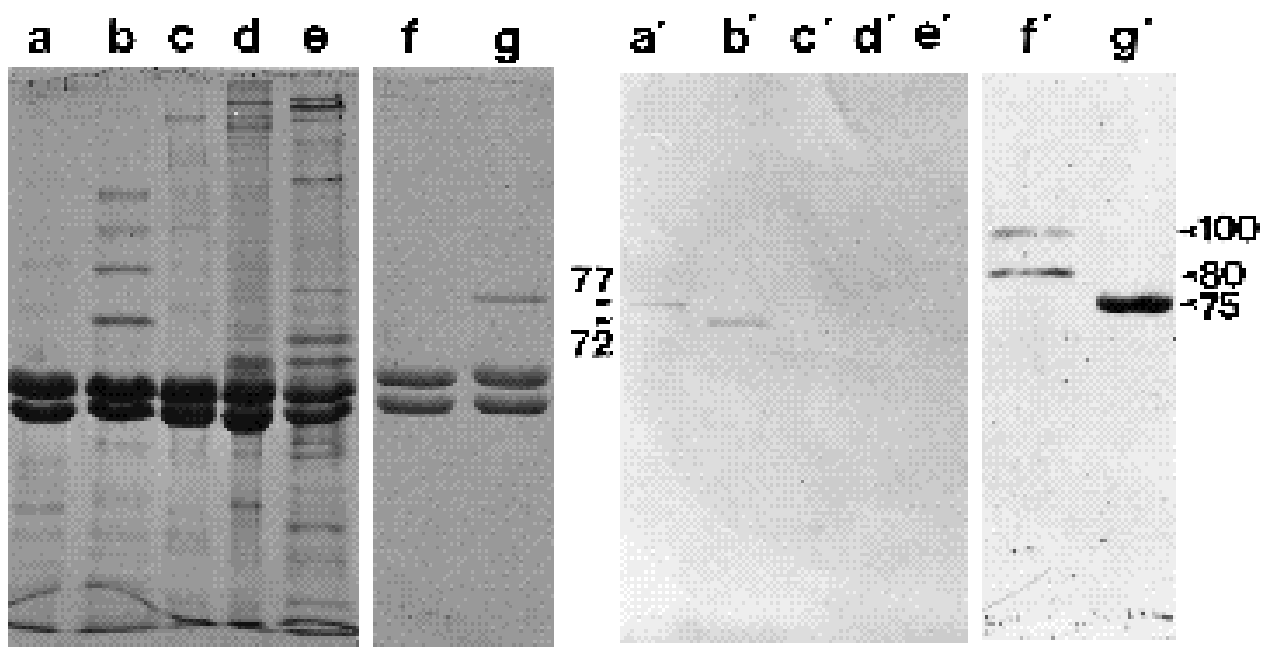

Fig. 8. Starfish and sand dollar MAPs are antigenically related to the $77,000 M_{\mathrm{r}}$ sea urchin MAP.

Microtubule protein was purified from sea urchin eggs $(S$. purpuratus, a; A. punctulata, g), starfish oocytes (b), surf clam oocytes (c), squid optic lobes (d), bovine brain (e), and sand dollar eggs (f), and analyzed by SDSPAGE. Their corresponding immunoblots with the affinitypurified anti-77,000 $M_{\mathrm{r}} \mathrm{IgG}$ are shown in $\mathrm{a}^{\prime}-\mathrm{g}^{\prime}$. The antibody recognizes a $72,000 M_{\mathrm{r}}$ starfish MAP and 75,000 $M_{\mathrm{r}}$ and 77,000

$M_{\mathrm{r}}$ sea urchin MAP; however in sand dollars, two polypeptides of $M_{\mathrm{r}} 80,000$ and 100,000 are detected. There is no cross-reacting polypeptide detected in surf clam, squid or mammalian brain microtubules. 

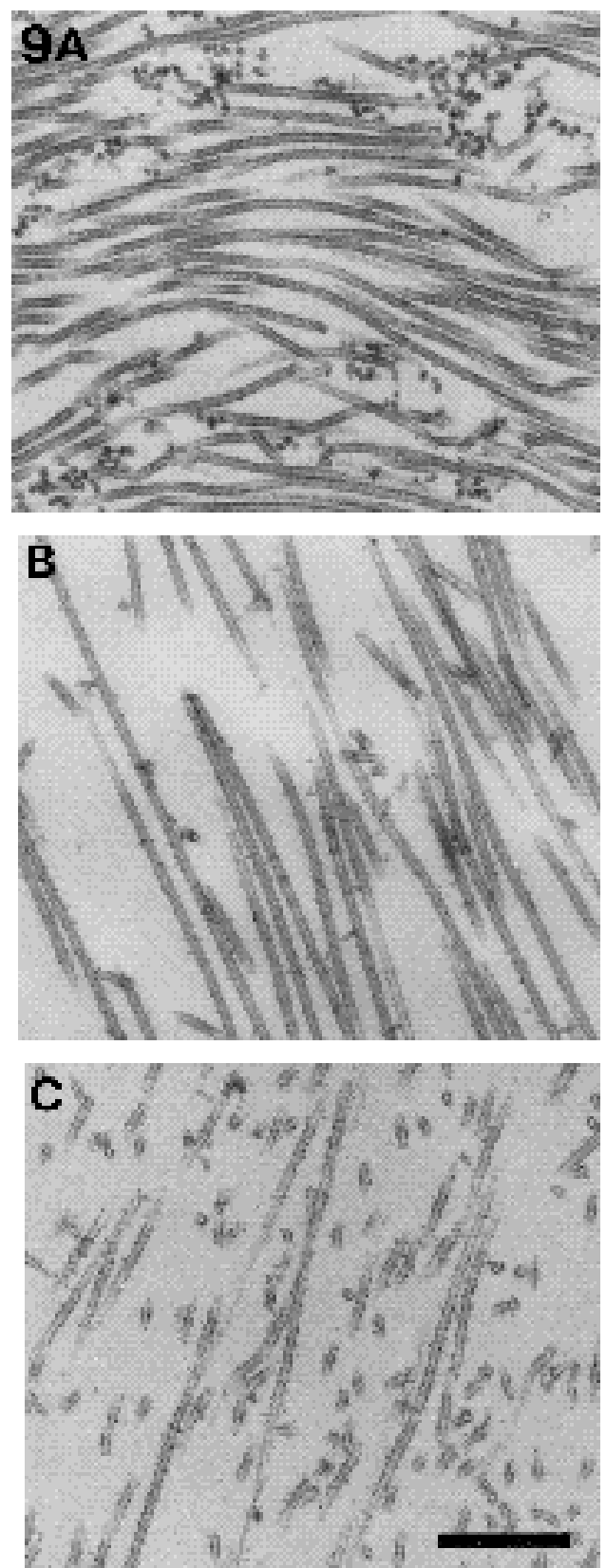

Fig. 9. Ribosomes are abundant in sea urchin (A. punctulata) microtubule preparations (A). These microtubules were pelleted, fixed and thin-sectioned for electron microscopy. Thre are no detectable ribosomes in identically prepared microtubules from surf clams (B) and mammalian brain (C). In contrast, these microtubules are decorated with fuzzy, filamentous projections. Bar, $400 \mathrm{~nm}$.

Removal of the EMAP results in the loss of microtubuleassociated ribosomes. EMAP cosediments with sea urchin egg microtubules that are purified by three cycles of $\mathrm{pH}-$ and temperature-dependent assembly and subsequently stabilized with taxol. Washing these taxol-stabilized microtubules with microtubule assembly buffer fails to remove any appreciable quantity of the EMAP and numerous ribosomes remain attached along the surface of these pelleted microtubules (Fig. 10). However, subsequent washing of

\section{S P Mt}

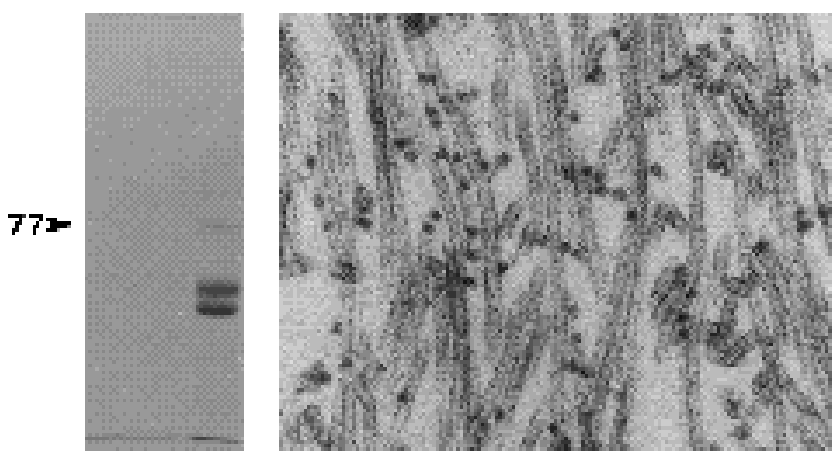

\section{$\mathbf{S}^{\prime} \mathbf{P}^{\prime} \mathbf{M t}^{\prime}$}

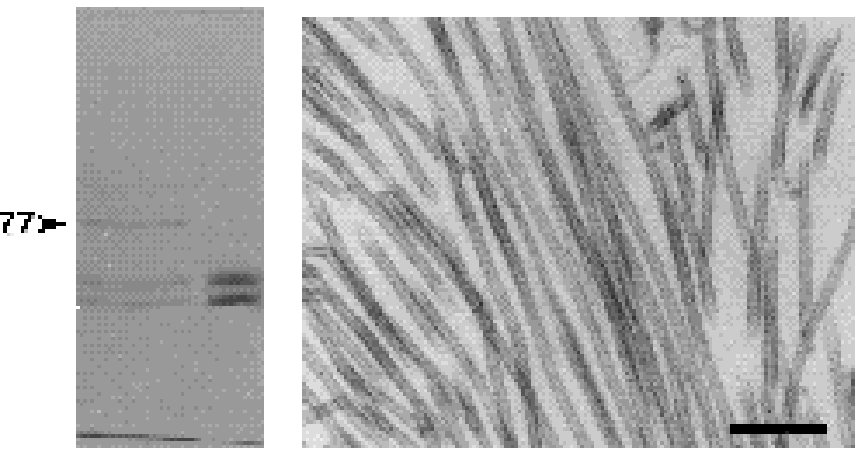

Fig. 10. Salt-extraction of the EMAP also results in the loss of microtubule-associated ribosomes. Sea urchin microtubules $(S$. purpuratus) were assembled in the presence of $20 \mu \mathrm{M}$ taxol and 1 $\mathrm{mM}$ GTP for $3 \mathrm{~min}$ at $37^{\circ} \mathrm{C}$, pelleted at $18,000 \mathrm{revs} / \mathrm{min}$ (JA20) for 30 minutes and subsequently analyzed by SDS-PAGE and electron microscopy. There are no detectable microtubule proteins in the $18 \mathrm{~K}$ supernatant $(\mathrm{S})$, while tubulin and the $77,000 M_{\mathrm{r}}$ EMAP are the major microtubule proteins found in the pellet $(\mathrm{P})$. Electron microscopy reveals that these microtubules (Mt) are decorated with many darkly stained ribosomes. In contrast, when sea urchin microtubules are polymerized in the presence of taxol, GTP and $0.35 \mathrm{M} \mathrm{NaCl}$, the 77,000 $M_{\mathrm{r}}$ EMAP is found in the supernatant $\left(\mathrm{S}^{\prime}\right)$ and is not detected in the pellet $\left(\mathrm{P}^{\prime}\right)$. These microtubules $\left(\mathrm{MT}^{\prime}\right)$ are also strikingly devoid of ribosomes. Bar, $200 \mathrm{~nm}$.

the egg microtubles with assembly buffer containing 0.35 $\mathrm{M} \mathrm{NaCl}$ results in the complete removal of the EMAP and the associated ribosomes. These results suggest that ribosome-microtubule interactions may be mediated through the EMAP.

\section{DISCUSSION}

In this report, we establish the identity of an echinoderm microtubule-associated protein or EMAP. EMAP is identified as a microtubule-associated protein because it copurifies with microtubules isolated from sea urchins, starfish and sand dollars, and a monospecific antibody against the EMAP localizes to microtubules in the mitotic apparatus and the cytoplasmic microtubule complex in interphase cells. The EMAP is not restricted to microtubules during a 
particular stage of the cell cycle nor is it restricted to a particular cell type, as it is found in oocytes, eggs and adult coelomocytes. EMAP is restricted, however, to echinoderms. Within the Phylum Echinodermata, the EMAP was detected in oocytes prior to meiosis and in mature eggs, in both embryonic and adult cells, and on mitotic as well as interphase microtubule arrays. EMAP was abundant in the Class Asteroidea (starfish) and both "Regularia" (sea urchin) and "Irregularia" (sand dollar) Echinodea subclasses. EMAP was not detected, however, in embryonic or somatic cells of marine molluscs from the Class Bivalvia (surf clam) or the Class Cephalopoda (squid). In addition, EMAP cross-reactivity was not found in bovine brain microtubule preparations or in mouse B16 cultured melanoma cells.

Biochemical studies indicate that EMAP is a unique polypeptide, perhaps unrelated to the vertebrate MAPs. EMAP is not thermo- or acid-stable, nor does it cross-react with antibodies against MAP-2 and tau. The EMAP antiserum does not recognize any bovine brain MAPs. However, these results do not preclude the possibility that there is a functional EMAP homologue in these organisms; the antiserum may recognize only the most evolutionarily related polypeptides. Future molecular studies will determine whether EMAP shares any sequence or perhaps functional homology with the more extensively characterized MAPs.

In this paper, we have shown that EMAP is antigenically related to the previously identified 75-80,000 $M_{\mathrm{r}}$ taxol MAP (Vallee and Bloom, 1983; Bloom et al., 1985; Scholey et al., 1984; Hirokawa and Hisanaga, 1987; Hosoya et al., 1990) and 80,000 $M_{\mathrm{r}}$ spindle MAP (Keller and Rebhun, 1982; Rebhun et al., 1982). The antiserum against the 77,000 $M_{\text {r }}$ cycle-purified MAP reacts strongly and specifically with both the taxol and spindle MAP. Moreover, a monoclonal antibody, S.P. 77-2, prepared against the $77,000 M_{\mathrm{r}}$ taxol MAP, reacts strongly with the EMAP on western blots (antibody kindly provided by R. Vallee, Worcester Foundation, Worcester, MA) (data not shown). Both the polyclonal antibody against the cycle-purified MAP and the monoclonal antibody against the taxol-MAP stain microtubules of the mitotic spindle apparatus and phagocytic amoebocyte (this report, and Bloom et al., 1985). In addition, both antisera fail to recognize any antigenically related polypeptide in sperm flagella. From these results, it is likely that the taxol-, spindle- and cycle-purified MAPs are the same protein.

Prior to this report, the relationship among the various sea urchin MAPs had not been established. It was premature to assume that they might be the same molecule because it was shown previously that mitotic cytoskeletons isolated from the spiny red urchin, Strongylocentrotus fran ciscanus, contained several proteins that migrated from 74,000 to $80,000 M_{\mathrm{r}}$ on 2-D SDS-polyacrylamide gels (Leslie and Wilson, 1989). This raised the possibility that there were several different MAPs in this $M_{\mathrm{r}}$ range with potentially different functions. On high-resolution SDSurea-acrylamide gels, there are frequently two to three bands in the 75,000 to $82,000 M_{\mathrm{r}}$ range, particularly in taxol-microtubule preparations (see Fig. 7). This heterogeneity is not restricted to taxol-microtubule preparations.
Frequently, there are two bands of similar $M_{\mathrm{r}}$ in the cyclepurified preparations (see Fig. 1). With the exception of sand dollar microtubules, only a single, major polypeptide reacts with the EMAP antiserum. It was suggested in a brief report (Scholey et al., 1985), that a minor 78,000 $\mathrm{Mr}_{\mathrm{r}}$ polypeptide in the taxol-microtubule preparations is a lowaffinity microtubule-binding protein. Immunolocalization studies suggest that the $78,000 M_{\mathrm{r}}$ antigen is mitotic spindle-associated, but not necessarily microtubule-associated in vivo. Understanding the function of these polypeptides, and their relationship to the EMAP, awaits further study.

What is the function of the EMAP? Since the immunolocalization studies indicate that the EMAP is present on both cytoplasmic and spindle microtubules, it is unlikely that the EMAP functions only in mitosis. However, recent studies indicate that microtubule dynamics during the cell cycle may be controlled through the actions of the cdc2 (Verde et al., 1990; Faruki et al., 1992) and mitogen-activated protein kinases (Gotoh et al., 1991; Hoshi et al., 1992). Although the in vivo targets for these enzymes are unknown, it is possible that the EMAP could be phosphorylated by one of these pathways and subsequently bring about a cell cycle-dependent change in microtubule dynamics.

Another potential function for the EMAP is in the association of ribosomes with the cytoskeleton. Previously, work from our laboratory has shown that ribosomes are attached to microtubules purified from unfertilized sea urchin eggs (Suprenant et al., 1989). The ribosomes are attached to the walls of the microtubules through a long tapered stalk of unknown composition. It is tempting to speculate that the stalk is entirely, or in part, composed of the EMAP. The stalks and ribosomes are removed in the presence of $0.35 \mathrm{M} \mathrm{NaCl}$; this salt concentration also removes the 77,000 $M_{\mathrm{r}}$ MAP from taxol-stabilized microtubules (this report; and Vallee and Collins, 1986). Ribosomes are attached by a tapered stalk to egg microtubules purified from all four sea urchins used in this study (Suprenant et al., 1989). While it is only correlative, it is interesting that ribosomes are absent from microtubules isolated from surf clams, squid, bovine brain and mouse B16 cells; cells and tissues where the EMAP is also absent. These results indicate that the EMAP may be specifically involved in the interaction of the translational machinery with the cytoskeleton.

Messenger RNA is not randomly or uniformly distributed throughout the cytoplasm of eukaryotic cells. Recently, it was shown that the cytoplasmic localization of Vg1 RNA in Xenopus (Yisraeli et al., 1990) and bicoid RNA in Drosophila (Pokrywka and Stephenson, 1991) is dependent upon microtubule integrity. It is intriguing to speculate that we have purified a functional ribosome-microtubule complex from sea urchin eggs that is capable of binding and translocating specific mRNAs during early development.

Kathleen Dean, Julie McKee and Shelly Hake were all undergraduate biology majors at the University of Kansas. Ms. Hake was supported by the Research Experiences for Undergraduates Program at the NSF. The authors thank Drs. L. Binder and R. Vallee for generously providing antibodies, Dr. P. Kitos for the cultured B16 cells, and Drs. R. Himes and W. Dentler for criti- 
cally reading the manuscript. This research was supported by a R.D. Allen Summer Fellowship (1988) at the Marine Biological Laboratory and a grant from the National Science Foundation (DCB-9003544).

\section{REFERENCES}

Baas, P. W., Pienkowski, T. P. and Kosik, K. S. (1991). Processes induced by tau expression in sf 9 cells have an axon-like microtubule organization. J. Cell Biol. 115, 1333-1344.

Balczon, R. and Schatten, G. (1983). Microtubule-containing detergentextracted cytoskeletons in sea urchin eggs from fertilization through first cleavage. Cell Motil. 3, 213-226.

Bibring, T. and Baxandall, J. (1977). Tubulin synthesis in sea urchin embryos: Almost all tubulin of the first cleavage mitotic apparatus derives from the unfertilized egg. Dev. Biol. 55, 191-195.

Bibring, T. and Baxandall, J. (1981). Tubulin synthesis in sea urchin embryos. II. Ciliary A tubulin derives from the unfertilized egg. Dev. Biol. 83, $122-126$.

Blake, M. S., Johnston, K. H., Russell-Jones, G. J. and Gotschlich, E. C. (1984). A rapid, sensitive method for detection of alkaline phosphataseconjugated anti-antibody on Western blots. Anal. Biochem. 136, 175179.

Bloom, G. S., Luca, F. C., Collins, C. A. and Vallee, R. B. (1985). Use of multiple monoclonal antibodies to characterize the major microtubuleassociated protein in sea urchin eggs. Cell Motil. 5, 431-446.

Dinsmore, J. H. and Solomon, F. (1991). Inhibition of MAP2 expression afects both morphological and cell division phenotypes of neuronal differentiation. Cell 64, 817-826.

Edds, K. T. (1985). Morphological and cytoskeletal transformation in sea urchin coelomocytes. In Blood Cells of Marine Invertebrates: Experimental Systems in Cell Biology and Comparative Physiology, pp. 53-74. Alan R. Liss, Inc., New York.

Faruki, S., Doree, M. and Karsenti, E. (1992). cdc2 kinase-induced destabilization of MAP2-coated microtubuls in Xenopus egg extracts. $J$. Cell Sci. 101, 69-78.

Gorovsky, M. A., Carlson, K. and Rosenbaum, J. L. (1970). Simple method for quantitative densitometry of polyacrylamide gels using Fast Green. Anal. Biochem. 35, 359-370.

Gotoh, Y., Nishida, E., Matsuda, S., Shiina, N., Kosako, H., Shiokawa, K., Akiyama, T., Ohta, K. and Sakai, H. (1991). In vitro effects on microtubule dynamics of purified Xenopus M phase-activated MAP kinase. Nature 349, 251-254.

Harris, P., Osborn, M. and Weber, K. (1980). Distribution of tubulincontaining structures in the egg of the sea urchin Strongylocentrotus purpuratus from fertilization through first cleavage. J. Cell Biol. 84, 668679.

Hirokawa, N. and Hisanaga, S-L. (1987). "Buttonin", a unique buttonshaped microtubule-associated protein $(75 \mathrm{kD})$ that decorates spindle microtubule surface hexagonally. J. Cell Biol. 104, 1553-1561.

Hoshi, M., Ohta, K., Gotoh, Y., Mori, A., Murofushi, H., Sakai, H. and Nishida, E. (1992). Mitogen-activated protein-kinase-catalyzed phosphorylation of microtubule-associated proteins, microtubuleassociated protein 2 and microtubule-associated protein 4, induces an alteration in their function. Eur. J. Biochem. 203, 43-52.

Hosoya, N., Hosoya, H., Mohri, T. and Mohri, H. (1990). A 70 kD Microtubule-binding protein from starfish eggs: Purification, characterization and localization during meiosis and mitosis. Cell Motil. Cytoskel. 15, 168-180.

Kanai, Y., Takemura, R., Oshima, T., Ihara, Y., Yanagisawa, M., Masaki, T. and Hirokawa, N. (1989). Expression of multiple tau isoforms and microtubule bundle formation in fibroblasts transfected with a single tau cDNA. J. Cell Biol. 109, 1173-1184.

Keller, T. C. S. and Rebhun, L. I. (1992). Strongylocentrotus purpuratus spindle tubulin. I. Characteristics of its polymerization and depolymerization in vitro. J. Cell Biol. 93, 788-796.

Laemmli, U. K. (1970). Cleavage of structural proteins during the assembly of the head of bacteriophage T4. Nature 227, 680-685.

Leslie, R. J. and Wilson, L. (1989). Preparation and characterization of mitotic cytoskeletons from embryos of the sea urchin Strongylocentrotus francisanus. Anal. Biochem. 181, 51-58.
Lewis, S. A., Ivanov, I. E., Lee, G.-H. and Cowan, N. J. (1989). Organization of microtubules in dendrites and axons is determined by a short hydrophobic zipper in microtubule-associated proteins MAP2 and tau. Nature 342, 498-505.

Lindwall, G. and Cole, R. D. (1984). The purification of tau protein and the occurance of two phorphorylation states of tau in brain. J. Biol. Chem. 259, 12241-12245.

Lowry, O. H., Rosebrough, N. J., Farr, A. L. and Randell, R. J. (1951). Protein measurements with the Folin-phenol reagent. J. Biol. Chem. 193, 265-275.

Melan, M. A. and Sluder, G. (1992). Redistribution and differential extraction of soluble proteins in permeabilized cultured cells. Implications for immunofluorescence microscopy. J. Cell Sci. 101, 731743.

Olmsted, J. B. (1986). Microtubule-associated proteins. Annu. Rev. Cell Biol. 2, 421-457.

Otto, J. J., Kane, R. E. and Bryan, J. (1979). Formation of filopodia in coelomocytes: Localization of fascin, a 58,000 dalton actin cross-linking protein. Cell 17, 285-293.

Pereira, A., Doshen, J., Tanaka, E. and Goldstein, L. S. B. (1992). Genetic analysis of a Drosophila microtubule-associated protein. J. Cell Biol. 116, 377-383.

Pokrywka, N. J. and Stephenson, E. C. (1991). Microtubules mediate the localization of bicoid RNA during Drosophila oogenesis. Development 113, 55-66.

Raff, R. A., Greenhouse, G., Gross, K. W. and Gross, P. R. (1971). Synthesis and storage of microtubule proteins by sea urchin embryos. $J$. Cell Biol. 50, 516-527.

Rebhun, L. I., Suprenant, K., Keller, T. C. S. and Folley, L. (1982). Spindle and cytoplasmic tubulins from marine eggs. Cell Differ. 11, 367371

Scholey, J. M., Neighbors, B., Grissom, P. and McIntosh, J. R. (1985). Location of 2 spindle polypeptides which exhibit different distributions in dividing sea urchin eggs. J. Cell Biol. 101, 31a.

Scholey, J. M., Neighbors, B., McIntosh, J. R., Salmon, E. D. (1984). Isolation of microtubules and a dynein-like MgATPase from unfertilized sea urchin eggs. J. Biol. Chem. 259, 6516-6525.

Smith, D. E. and Fisher, P. A. (1984). Identification, developmental regulation, and response to heat shock of two antigenically related forms of a major nuclear envelop protein in Drosophila embryos: Application of an improved method for affinity purification of antibodies using polypeptides immobilized on nitrocellulose blots. J. Cell Biol. 99, 2028.

Smith, V. J. (1981). The Echinoderms. In Invertebrate Blood Cells (ed. Radcliffe, N. A. and Rowley, A. F.), vol. 2, pp. 513-562. New York: Academic Press.

Suprenant, K. A. (1986). Tubulin-containing structures. Methods Cell Biol. 27, 189-215.

Suprenant, K. A. and Marsh, J. C. (1987). Temperature and pH govern the assembly of microtubules from unfertilized sea urchin egg extracts. $J$. Cell Sci. 87, 71-84.

Suprenant, K. A. and Rebhun, L. I. (1983). Assembly of unfertilized sea urchin egg tubulin at physiological temperatures. J. Biol. Chem. 258, $4518-4525$

Suprenant, K. A., Tempero, L. B. and Hammer, L. B. (1989). Association of ribosomes with in vitro assembled microtubules. Cell Motil. Cytoskel. 14, 401-415.

Vallee, R. B. and Bloom, G. S. (1983). Isolation of sea urchin egg microtubules with taxol and identification of mitotic spindle microtubuleassociated proteins with monoclonal antibodies. Proc. Nat. Acad. Sci. USA 80, 6259-6263.

Vallee, R. B. and Collins C. (1986). Purification of microtubules and microtubule-associated proteins from sea urchin eggs and cultured mammalian cells using taxol, and use of exogenous taxol-stabilized brain microtubules for purifying microtubule-associated proteins. Methods Enzymol. 134, 116-138.

Verde, F., Labbe, J.-C., Doree, M. and Karsenti, E. (1990). Regulation of microtubule dynamics by cdc2 protein kinase in cell-free extracts of Xenopus eggs. Nature 343, 233-238.

Weingarten, M. D., Lockwood, A. H., Hwo, S-Y. and Kirschner, M. W. (1975). A protein factor essential for microtubule assembly. Proc. Nat. Acad. Sci. USA 72, 1858-1862.

Wiche, G., Oberkanins, C. and Himmler, A. (1991). Molecular structure 
and function of microtubule-associated proteins. Int. Rev. Cytol. 124, 217-273.

Williams, R. C. and Detrich, H. W. (1979). Separation of tubulin from microtubule-associated proteins on phosphocellulose. Accompanying alteractions in concentrations of buffer compoenents. Biochemistry 12, 2499-2503.

Yisraeli, J. K., Solkol, S. and Melton, D. A. (1990). A two-step model for the localization of maternal mRNA in Xenopus oocytes: involvement of microtubules and microfilaments in the translocation and anchoring of Vg1 mRNA. Developement 108, 289-298.

(Received 14 July 1992 - Accepted, in revised form, 21 October 1992) 